\title{
Protection of Personal Data Requirement of Modern Times for the Functioning of the Security, Individual Freedoms and the Rule of Law
}

Mrsc. Ruzhdi Jashari, Phd.cand.

\begin{abstract}
Rule of law, human rights, freedoms, and security; are the three main pillars to the new trend of global developments, especially in the development of democratic values, where the protection of individual freedoms is among the fundamental principles that have data protection as the center point. In the years 2015-2016 we have seen the major cases of confrontation regarding the wiretapping to that point as the intervention even in the system of the "US election campaign by the Russian hackers", then sending of Macedonia to the "early elections, due to the extraction and publication of wiretaps by Zaev", the review of the "Safe Harbor" Agreement, of the EU and the US regarding the transfer of personal data during free "transatlantic" trade among EU and USA, etc. In this time of globalization, and developments of major movements is been said: "no home", "no time", "no limit", by digitized devices and social networks, privacy of the individual is excessively violated through abuse of personal data, personal security is violated and security of the systems vital to society. Therefore, this way, the national security of a country is been violated and endangered as well. Therefore, the development of institutions for protection of personal data, their independence and empowerment are of particular importance due to the vital interests of the country; where security, justice and freedom have a leading role in the development of a free and democratic society, where the individual human rights and freedoms, have a main place in modern developments of our time, in the society with the rule of law and the diversity of values. Freedoms and human rights, data and privacy protection; according to the European Convention of freedoms and human rights and the 108 Convention of the protection of personal data in automated processing, even though Kosovo has still not signed them. These rights are guaranteed by the constitution. On May 26, 2018 New Rules for the Protection of Personal Data of the EC and the European Union, will be no binding power for all EU countries. The entire legal measures of protection of personal data of the new Rules of PPD, should be forwarded to legislation interior PPD of EU member states and the EC and those who are already signatories to Convention 108 of PPD during the automatic processing of personal data. Among other things, we will give our assessments in question, where Kosovo really stands in this direction, with its commitment and aspirations for integration into European institutions and mechanisms.
\end{abstract}

Keywords: Protection of personal data, security, rule of law, human rights and human freedoms

\section{Introduction}

In novadays the "Rule of law", or "law implementation", is an expression that is being used in daily political and journalistic jargon, in all countries at the Internationl level. Certainly law enforcement gives in for the spirit of democracy development, the state of stability strength and boosts confidence in state institutions. Meanwhile, guarantee and respecting of the "Human rights and freedoms" at the time of the modern developments of human society, are state obligations arising from the Universal Declaration of Human Rights (UDHR,1948) and at the same time the indicator and guide of democracy values. It is said that with the right that; "Where there is respect for human rights the democracy is progressed".

But for creating an environment for the development of democracy, respecting human rights and fundamental freedoms and the rule of law, the rule of law is indispensable security. Security as a term is very broad. Today, lots of modern safety studies have been advanced, which are at the center of studies for international relations.

The concept of threats has changed so much that "Security Studies include within their risks ranging from pandemics such as HIV / AIDS and environmental degradation to safety concerns associated with direct violence, conflict and inter-state terrorism" (Collins, 2013:15). Equally in the current international setting phenomenon of interference with privacy has become a serious concern for humanity. Thus the abuse of personal data does not exclude to any social class and gender new age. So, from our point of view the intervention in personal data threatens the security of the individual and 
contemporary security studies in their studies should also address the security of personal data, where the referring object is an individual.

Everything is okay in this regard while many scholars agree that the overall security implying here; human security, state, politics, economic, military and the environment are a priority to enable the development of democratic values, where the protection of personal data constitutes a fundamental value of individual freedoms and stands on the principle issue of the Universal Declaration of Human Rights and Freedoms of UN (UDHR: 1948). On the theory of human rights states that "where is protected the privacy and personal data right there is flourishing of human rights".

Therefore, in addition to the paperwork will try to point out the role of personal data protection, as a contribution to the function of law enforcement implementation, as an assistance in respecting of freedoms and human rights as well as the instrument or added growth of value of the security of the individual, local (state level), regional all the way to international level.

Of course the protection of personal data and individual privacy, the faster development of digital technology, have greater concerns for humanity, towards the improvement of working conditions and better men's life, because of the numerous possibilities of violating of privacy and abuse of personal data. Therefore, for this reason already, is under development a major debate at all levels of human society.

Finally, our effort now is to see, how much space it has, and that how much is included in the protection of personal data in modern safety science, as one of the challenges of the time security science, it adds quality to one of the theories missing and without treatment within them. Out separately in the context of human security, the protection of personal data will be one of the topics to be addressed with interest within contemporary security studies.

\section{The protection of personal data in function of the rule of law}

Risks that are being brought by automation of technology, without underestimating larger benefits to humanity, are affecting to the infringement of individual privacy. Therefore, the concern of citizens for their own safety, their rights and freedoms in the sphere of personal data protection are essential attributes of democracy development in society and rule of law.

State obligations of Kosovar society in fulfillment of standards in terms of the requirements of the Visa Liberalization and Stabilization - Association for Kosovo, are obligations also asked the EU and the EC to meet the pillar of justice - freedom and security, where protection and security of personal sample data is of particular priority in this area.

In this time of modern technological developments and developments with dizzying speed to free trade within the global market, legal protection of personal data is obligatory for all human society at international level and not only the obligation of a country, region or continent. So, the huge influx of international circulation of personal data, has led to transnational crime that has crossed state borders", that are affecting the jurisdiction of neighboring countries" (United Nations Convention Agains Transnational Organized Crime, 2000).

Lack of knowledge and a greater need for the development of this field not only in Kosovo but also in the region and at international level, which is new and comes as a challenge of times, parallel with the rapid technology development of the "digital world", it increases the need for knowledge and cognition in this field; to be systemized, to be taught and studied, up to academic levels, as part of a "new field", perhaps of "theory for the protection of personal data".

The fulfillment of legal requirements for harmonization of legislation of Council of Europe member states, the EU and those that aspire to membership in the European Union with "aqui comunitiare", with regard to legal certainty and the protection of personal data, are also obligations for European integration and are more dimensional interest to humanity in every corner of the world to the globalization process, where one moves with "his indivisible property" of so called personal data.

However, harmonization of domestic legislation with the 108 Convention, adopted in 1981 by the Council of Europe regarding the protection of personal data during automatic processing, then issuing the special law on the protection of personal data pursuant to Directive 95/46, are vital for Kosovo, in its roadmap towards EU integration and euro - Atlantic institutions. Kosovo already has "the personal data protection law" (03 / L - 172: 2010) and "institution for supervising of this law" (NAPDP: 2011). The challenge that must be prepared by the Kosovo institutions on legal harmonization and incorporation of new bringing at the European level in this area (on the protection of personal data) when we consider the EC's new regulation and the EU Protection Agency Personal Data (New Regulation EC and the EU for the Protection of 
Personal Data, 2016), obliges the executive and the legislature of the country to be at the level of duties and responsibilities entailed in time before them.

Based on international law, the freedoms and fundamental human rights, focusing on "the protection of individual freedoms", in terms of binding international cooperation, these rights become part of positive international law and "them once and permanently cease to be a matter of exclusive competence of states and become legal issues of concern to the international community". Gruda (2013: 421).

Where does Kosovo stand in this regard?

The reality is the fragility of institutions and lack of political responsibility; the citizens of Kosovo are still far from taking in due time service in the field of personal data protection, which it has guaranteed the country's constitution. These rights with no doubt have an impact on the rule of law sector, a vital sector to fighting crime and corruption, where Kosovo, from various international reports, it is ranked as the country with the highest involvement in corruption and organized crime.

Whereas, although Kosovo has an advanced law and the best in the region since the end of the first five-year mandate of the agency supervisors, on June 30, 2016 until today (April 30 2017), the negligence of the central institutions and supposedly "suggestion of the EU office in Pristina; initially to review the law on protection of personal data, then made the election and appointment of state agency supervisors ", it "suspends the work of the institution - of the agency". We can freely say that people with this access was denied in practice their rights for a long time and years in getting services guaranteed by the constitution and the law, and also, lots of times it avoids Kosovo in the roadmap and its aspirations to European integration, a move that temporarily suspends enforcement of the law.

So this wrong approach to establish constitutional institutional vacuum that the Constitution does not recognize and irresponsibility of Kosovo's central institutions creates institucioinal cramps. Such vacume in the legal space of the European Union are not known.

\section{Protection of personal data in the background of human rights and freedoms}

Human rights and justice in the rule of law and the rule of law, meaning if the unjust gets hit, and it hits the violations of human rights and freedoms. Already in the world the dimension of humanism of humanity, slowly takes the leading role, which reflects the hope of lasting peace for which we all, globally, in every corner of the terrestrial globe, need to be devoted contributors. We have seen the case of international intervention in 1999 of the international community in Kosovo, when under the sovereignty of Serbia were violated human rights of Albanians, was just a concept on paper. Then, finally, when from the Assad's chemical poisons in Syria were killed hundreds of civilians most of them children, were hit Syrian military targets, by the US military forces with tomahawk missiles, without even consulting the sovereignity of this country, in defense of the values of humanism and of freedom: http//periskopi.com/publikohet-videoja-e-sulmit-amerikan-mbi-sirine, accessed 08/04/2017

Freedoms and human rights are numerous references in social science studies. Based on the theory of international relations, many schools advance their contemporary studies on universal human rights. Even modern diplomacy promotes in practice and in theory, human security at the international level, based on the basic principles of the Universal Declaration on Freedom and Human Rights (UDHR, 1948).

"Essential (sin qua non') condition of the liberal state, in all its versions, is the power and authority of the government, is limited by a constitutional system of rules, in which are respected individual freedom and equality before the law". (Gray, 1986: 107)

In the background of human rights and freedoms, where personal data is related to the dignity of the individual, is been placed on the principle number one of the Universal Declaration of Human Rights and Freedoms, now at the international level, has reflected a host of conventions, Protocols, Regulations, Declarations, Directives, Treaties and Agreements that guarantee the protection of personal data, individual freedoms and the right to privacy of an individual.

Society with modern political and constitutional systems, today are considered all those states that have built their constitutions of the wider respect of human rights and freedoms. At the international level in this regard the European Union leads where in addition to advancing respect for human rights in the justice system has two courts; that of Justice (ECJ) in Luxembourg and that of Human Rights and Freedoms (ECHRF) in Strasbourg. 
The basic definition of the concept of individual rights, of course, comes from data security through the systems security in public and private institutions that hold and process personal data of citizens by guaranteeing them legal processing and legal basis of personal data through the rule of law.

While the higher standards of protection of personal data, the higher is the confidence and scale of human freedom rights, inasmuch much more improved are standards of democracy. This issue of the security of personal data, the "lower" or "consolidated", is a good indicator and one of the indicators of democratic development and security of a country. Besides increasing confidence in state institutions in this regard, the main beneficiary is the citizen.

At this time of dynamic technological developments that "For the man in the future will suffice as the" identity card "only the fingerprints stored on the computers of international police stations" (Dimas, 2008:398). Undoubtedly the protection of personal data is also affected by the levels of protection and data security at the regional and international level.

High risk level of data in the global level, in novadays represent the so called processors of data that are called "Big Data", with "bad transparency of provider services, vague locations for their data, disclosure of personal data,...the impossibility of continuing with implementation of security policies...disclosure of data during the transfer", etc.

Strengthening and advancement of human freedom that comes naturally from the speed rate of harmonization of domestic legal norms and instruments, with European privacy framework and conventions and human rights. As much as these acts are harmonized, much higher are standard on human rights and the higher security and vice versa; where the aspects of addiction for Kosovo and the region has to do with the positive dependence and is in accordance with the requirements of the SAA and European integration.

Personal rights, with the emphasis on the Copenhagen School; on the social identity, social security, protection of social identity, threats towards the social identity and social security dilemmas, under the light of integrational processes in Western Europe and the disintegration of Eastern Europe, it says that: "Social Security as a concept was perceived as a reaction to events in Europe, both in the East and in the West "(Collins, 2013:216, 217) where the democratic development of system of values, have advanced more in the field of personal rights. So, then the social security has to do with the preservation of collective identity, including personal rights of all individual identities of citizens.

Whereas seen from the aspect of international terrorism action with international dimension, which is steadily increasing, according to the Copenhagen School on Security Contemporary Studies, we can say that "the greatest threat of freedoms and civil rights in a democracy, happens in those contexts where the battle against terrorism is seen as an equvalent to a war "(Collins, 213, 384), therefore, the concept of protection of personal data deserves special treatment in security sciences.

\section{Protection of personal data an important element of security}

The safety concept for a long time it was connected as "territorial security of countries from outside interference" as "protection against external aggression" as "as protection of national interests" or "as global security." In the period of globalization trends these concepts are relativized and seem as inappropriate. Theoretician and critic in the advancement of modern states system, includes the belief in creating of structures "cosmopolitan to better promote freedom, justice and equality around the world ... in an effort to fundamentally revalue normative foundations of world politics" (Burchill \& Linklater, 2010:196).

Such security concepts comprehend their expansion, taking into account the threats and risks already global, as: international terrorism, environmental problems, genocide and ethnic cleansing, health problems, fight against drugs, weak states and problematic for global security, poverty, religious extremism, cyber crimes etc.

However, in support of the Copenhagen school representatives, especially in the publication "Safety: a new analysis framework" (English "security: A New Framework for analysis") (1998) we find the definition that "security is about survival. Security called cure time as an issue is been presented as an existential threat to a defined referral object. "(Collins, 2013:151).

Therefore, from the point of view of security threats to personal data and the individual itself in this regard, we are dealing with the concept "anthropocentric", where the security problem it touches many areas and affects all levels of organized systems of human life where personal data lies. 
Therefore, in this liaison we distinguish:

- Horizontal level, taking into konsideration wide range of systems,

- Vertical level, taking into account the organization of state systems in its two sectors (public and private bodies)

- Systemic level, taking into account the organization of systems, especially as (public and private bodies)

The inevitable questions are?

Security, for whom? The answer is for referring-individual object. But, except the object (individual) as vice versa beneficiary it benefits the system (public-private body), state, region and beyond).

Security for what values? For the values of humanism, justice, rule of law, peace and welfare.

From what threats, who are they? The data abusers, processors and operating systems with personal data, (public-private and state bodies).

- Real threats, cyber attacks, intercepting systems, human factor etc.

- Potrential threats: within the system, over there where collected and where are processed.

- Threats: from beliefs, perceptions, poor knowledge of the individual and the state institutions.

What are the tools and what is the price of organization?

- A good political frame - Kosovo has it and the region as well,

- Independent Supervising Institution - Kosovo and the region hs erected those structures,

- The best system and independent judiciary, administrative measures to be applied in case of data security threats, where educational and soft measures have proved as ineffective,

- The cost of organizational expenses of authority is not great but rising costs in this regard favors the strengthening of all systems data security, where the national security, regional and wider in the center is the individual.

In this sense related to data security, the trends are positive. We highlight the fact that the European Directive on the protection of personal data is separate chapter regarding the security of personal data. Also, the special chapters have almost the laws for protecting of personal data to countries where this Directive has been transposed.

The laws for protection of personal data in Kosovo, with special provisions regulating the security of personal data in Article 14. While the same thing in terms of new Rules of the EC and the EU has also made new obligations on the private sector, related to their duties and obligations for appointment of protection officers of personal data in their companies http://www.pdpconferences.com/conferences-overview/136-the-new-data-protection-law-how-to-prepare-for-the-changes, seen on; 08/04/2017, at 18 o'clock, thus affecting to grow significantly the ambiance of data security. New regulation of data protection enforcement has an obligation to all EU countries starting from 26 May 2018. But much more work is required for activities and expertise about the practical implementation of legislation, the efficacy and safety to be growing.

\section{Recommendation}

From what was said above we recommend:

As preparations on the application of the new legal flows in the New Regulation of EU and EC Personal Data Protection, to be a fait accompli, that the European Community countries and those that aspire EU to start membership for the practical implementation of the new European law, immediately starting from 30/05/2018.

The authorities to be more efficient, and not to happen that the Governments and Parliaments of the states (as in the case of Kosovo) with their negligence create institutional vacuum by unabling the supervision of the implementation of the law in practice for data protection.

To be preserved the constitutional institutional independence of the institutions for protecting personal data. 
To be raising the knowledge and scientific knowledge in all levels of education, regarding the safety and protection of personal data, tht the state and society should be prepared for this new challenge of our time. Contemporary Science Security, to expand and to include the concept of human security, social security, political security, public safety etc; the deployment of new studies on the security of personal data. This will bring new favors to regional and international security.

To immediately be seen the possibilities of joint action platform of unique action in the international community about the protection and security of personal data and of personal data.

Manufacturers of digital technology, which is been applied in machining processes, operation and transfer of personal data to certify the technology related to security and privacy protection of personal data.

\section{List of abbreviations}

ASHMDHP-SAPPD / State Agency for Protection of Personal Data

UDHRF / Universal Declaration of Human Rights and Freedoms,

UE / European Union,

PE / European Parliament,

EC / European Council,

Pdp / Personal Data Protection,

DP / Data Protection,

PDP, dp / Personal Data Protection, Data protection,

\section{Literature}

\section{Books and different editions}

[1] Burchill, S., linklater, A. (2010): INTERNATIONAL RELATIONS THEORY,

[2] Title in the original: Theories of International Relations, Tiranë.

[3] Collins, A. (2013): STUDIME BASHKOHORE TË SIGURISË, 2013, Titulli në origjinal Contemporary security studies OXFORD PRESS UNIVERSITY UET Press, Tiranë, www.uet.edu.al/info@uet.edu.al.

[4] Dhima, A. (2010): INTRODUCTION TO ANTHROPOLOGY, Third Edition, idearti, Tirana.

[5] Gruda, Z. (2010): INTERNATIONAL PROTECTION OF HUMAN RIGHTS DOCUMENTS AND MATERIALS, fifth edition, "AUT" Pristina.

[6] Gruda, Z. (2013): International Public Law, 2013, Pristina.

[7] Grey, J.: Liberalism (t.o.Liberalism), 1986, Open University Press, translated by: Raxhimi, A .; published by the Institute of Dialogue and Communication, Tirana, ISBN 978-99956-750-7-3. (Institute of dialogue and communication, tel. ${ }^{+} 35542371865$ )

[8] Guidelines on handling complaints and claims for infringement of personal data on social networks and in cloud comuting.The projects its conducted with support of the Norwegian Ministry of Foreign Affairs for the Directorate for Personal Data Protection of Macedonia and personal data protection on Cloud computing, 2015.

\section{[9] Conventions, directives, laws and other documents}

[10] European Convention for the Protection of Personal Data during Automatic Processing 108 of the year 1981.

[11] The United Nations Convention against Transnational Organized Crime, 2000. 
[12] European Convention of Freedoms and the on Human Rights (1949) which entered into force in 1953, in Roma, Italy.

[13] Universal Declaration of Human Rights and Freedoms (1948)

[14] New Regulation of the EC and Parliament and the EC adopted on April 26, 2016 which is binding to apply to all EU member states by 26 May 2018.6. Law No.03/L-172 for the protection of personal data in the Republic of Kosovo, adopted on April 29, 2010 and entered into force on 30 May 2010.

[15] European Directive 95/46 of the European Parliament and of the Council of 24 October 1995 on the protection of individuals with regard to the processing of personal data and the free movement of such data.

[16] OFFICIAL GAZETTE OF REPUBLIC OF KOSOVO/ PRISTINE/ YEAR V /No. 70/ 31 MAY 2010, Law No.03/L172 for the protection of personal data, where data security is regulated by a special provision of Article 14 , subsection B Chapter II.

\section{[17] Pages from the Internet and the official institutional pages}

[18] WWW. dzlp.mk; seen on, 30. 04. 2016, at $24.00 \mathrm{~h}$.

[19] thttp: // periskopi.com/publikohet-videoja-e-sulmit-amerikan-mbi-sirine/, seen on 08. 04. 2017, at $18.00 \mathrm{~h}$.

[20] http://www.pdpconferences.com/conferences-overview/136-the-new-data-protection-law-how-to-prepare-forthe-changes, seen on 08.04.2017, at $18.00 \mathrm{~h}$.

[21] www.amdp-rks, seen on 30. 03. 2017, at $18.00 \mathrm{~h}$. 